\title{
IDEAS OF CHARACTER EDUCATION AT THE INTEGRATED ISLAMIC ELEMENTARY SCHOOL IN BANJARMASIN
}

\author{
Galuh Nashrulloh Kartika Majangsari Rofam \\ Universitas Islam Kalimantan Muhammad Arsyad Al Banjari \\ Email: ganartika.mayang@gmail.com
}

\begin{abstract}
Character problems are increasingly diverse that is evidenced by the increasing violence and criminal acts on children, pornography, drug abuse and other deviant acts. Integrated Islamic Primary School as one of the three types of elementary school institutions is expected to an alternative solution. This research focused on the analysis of ideas on character education at an Integrated Islamic Elementary School. This qualitative field research employed a phenomenological approach. The data were collected from the documents at the school, interview with the founders, and observation to triangulate the data. This research argued that the idea was to answer the needs of the local community, especially the upper middle class. The main purpose of education is to develop the potential of students' nature towards creating a generation with courageous and character leaders based on the Koran and the Sunnah. The 7 characters were instilled as a hallmark of character education at the school. These characters are adopted from Hassan Al-Banna's thought in "Tarbiyah's mission." This point confirmed Hasan's contention. However, there is a slight difference in terms of nationalism, namely that the school run a 5 pillar government program on character education (PPK) in implementing the school's vision and mission.
\end{abstract}

Keywords: Idea, Character Education, Integrated Islamic Primary School.

\begin{abstract}
Abstrak
Masalah karakter semakin beragam yang dibuktikan dengan meningkatnya kekerasan dan tindak kriminal pada anak-anak, pornografi, penyalahgunaan narkoba dan tindakan menyimpang lainnya. Sekolah Dasar Islam Terpadu sebagai salah satu dari tiga jenis lembaga sekolah dasar diharapkan menjadi solusi alternatif. Penelitian ini berfokus pada analisis gagasan tentang pendidikan karakter di Sekolah Dasar Islam Terpadu. Penelitian lapangan kualitatif ini menggunakan pendekatan fenomenologis. Data dikumpulkan dari dokumen di sekolah, wawancara dengan para pendiri, dan observasi untuk melakukan triangulasi data. Penelitian ini berpendapat bahwa idenya adalah untuk menjawab kebutuhan masyarakat setempat, terutama kelas menengah ke atas. Tujuan utama dari pendidikan adalah untuk mengembangkan potensi sifat siswa dalam menciptakan generasi dengan pemimpin karakter dan keberanian berdasarkan Alquran dan Sunnah. 7 karakter ditanamkan sebagai ciri pendidikan karakter di sekolah. Karakter-karakter ini diadopsi dari pemikiran Hassan Al-Banna dalam "misi Tarbiyah." Poin ini menegaskan pendapat Hasan. Namun, ada sedikit perbedaan dalam hal nasionalisme, yaitu bahwa sekolah menjalankan program pemerintah 5 pilar tentang pendidikan karakter (PPK) dalam melaksanakan visi dan misi sekolah.
\end{abstract}

Kata kunci: Ide, Pendidikan Karakter, Sekolah Dasar Islam Terpadu. 


\section{A. Introduction}

The issues surrounding the character or morals that occur today are much more complex than the problems that occurred in the past. This is characterized, among other things, by the increase of violence in adolescents and children, pornography, free sex, drug abuse, adolescent hostility and other bad habits that may be underestimated, such as cheating, bullying and other immoral acts. Children lose their sense of respecting to an older person. The widespread cases of sexual immorality perpetrated by these children have serious consequences and can not be regarded as a simple matter as such acts have in part lead to criminal acts. ${ }^{1}$

Facing global challenges, children are faced with many choices about values -good and bad that are interpreted with vague boundaries. Values that are well respected by a community group to be faded are replaced by new values that are not necessarily compatible with the culture of Indonesian society.

The condition indicates that the out put which is a product of an educational institution has not had a sense of conscience based on morality or sense of humanity, so it has not been able to achieve the substance of education that is placing humans on the highest degree by maximizing personal qualities.

All of these arguments are the reasons for the strengthening of character education in the nation's next generation, in line with the thought expressed by Thomas Lickona that there are ten signs that need attention to be anticipated in a better direction. The signs are: 1) increased violence among adolescents, 2) worse language and use of words, 3) strong peer-group influence in violence, 4) increased self-destructive behavior, such as drug use, alcohol and free sex. 5) the decline of good and bad moral guidance, 6) decline in work ethic, 7) the lower respect for parents and teachers, 8) the low sense of responsibility of individuals and citizens, 9) to defeat dishonesty, and 10) suspicion and hatred among others. ${ }^{2}$

The government's concern for character education was proven when the President of Indonesia declared the National Movement of Character Building on National Education Day on May 2, 2010,therefore since 2010 Character education is encouraged again through learning in Indonesia. Character education policy is published through the website of the Directorate General of Higher Education. There is a grand designcharactereducation on nationalpolicy of nationcharacterdevelopment 2010-2025, the master design of Character Education from Ministry of nationaleducation, direction andstages and Character Education priorities of the Year 2010-2025. ${ }^{3}$

Character education is implemented in formal education, non formal education and informal education as directed by the Ministry of National Education. Formal education is carried out through learning, co-curricular activities, extra-curricular, cultural creation of educational unit and habituation. As for non-formal education, character education takes place on courses, equality education, literacy education and other non-formal education institutions through learning, co-curricular activities, extracurricular activities, institutional

1 http:/ / liputan6.com/tag/kenakalan-remaja. [Accessed 27 September 2017].

2T. Lickona, Educating for Character: How Our Schools can Teach Respect and Responsibility, New York: Bantam Book, 1992, pp. 20-22.

${ }^{3}$ d. Muchlas Samani, Konsep dan Model Pendidikan Karakter, Bandung: Rosdakarya, 2013, p. 7. 
culture creation and habituation. While in informal education, character education is implemented in the family. ${ }^{4}$

Character education is expected to bring students toward cognitive value recognition, affective values appreciation, and ultimately the realization of values. This is the design of character education called by Thomas Lickona as moral knowing, moral feeling and moral action. ${ }^{5}$ Therefore, all subjects taught must reinforce character education that creates human character.

In the process of character education, students develop their potentials actively, internalize and apply the values of characters that are built into their personalities. So the ultimate goal of character education is to develop a more prosperous society, and develop the life of a dignified nation. ${ }^{6}$ Based on the national education function and objective of act No. 20 of article 3 of 2003 on National Education System, it is clear that education at every level from elementary to higher education must be designed and organized systematically in order to achieve these objectives.

The curriculum is one of the main components used as a reference in determining teaching materials, directing the process of educational mechanisms, as a benchmark of success and quality of education. ${ }^{7}$ If every process of education is character education, then character education occurs naturally when it is carried out naturally, because the process can occur everywhere-inside or outside the class--, so inevitably character education must be reflected in an educational institution through formal and hidden curriculum. ${ }^{8}$

Primary school as an institution that becomes a forum for the establishment of graduates who are characterized. Graduates who have character in accordance with the target institution is a reflection of the institution's success in implementing the vision and mission of education.

More specifically, the researcher is interested to examine more deeply about what makes the students of SDIT Ukhuwah have different character from other elementary school students in general, through the analysis of idea on character implementation. This is in line with what Hamid Hasan said in SyaifuddinSabda that the curriculum conceptually can be viewed from four perspectives: 1) curriculum as idea, 2) curriculum as written plan, 3) curriculum as process, and curriculum as a result of learning.9 In short, this research is focused on first, the analysis of the idea or idea of character education on the curriculum and documents at the Integrated Islamic Primary School (SDIT) Ukhuwah in Banjarmasin. Second, the implementation of character education on the curriculum of Integrated Islamic Primary School (SDIT) Ukhuwah in Banjarmasin.

${ }^{4}$ d. Muchlas Samani, Konsep dan Model Pendidikan Karakter, Bandung: Rosdakatya, 2013, pp. 21-22.

5M. Wahid, "Pengembangan Model Pendidikan Afeksi beroriantasi Konsiderasi Untuk Membangun Karakter Siswa ang Humanis di Sekolah Menengah Kejuruan," in The 4th International Conference on Teacher Education; Join Conference UPI \& UPSI, Bandung, 2010.

6T. Lichona, Educating for Character, New York: Batam, 1992, p. 51.

7D. Koesoema, Pendidikan Karakter Utuh dan Menyeluruh, Yogyakarta: Kanisius, 2016, p. 55.

8L. Hasibuan, Kurikulum dan Pemikiran Pendidikan, Jakarta: GP Press, 2010, p. 6.

9D. K. A, Pendidikan Karakter Utuh menyeluruh, Yogyakarta: Kanisius, 2016, p. 9. 
The curriculum as a written plan is a "recording" of all ideas that are poured in written form. If the written ideas or written documentsare the ideal curriculum, then the process of the written document implemented in the form of real is called a real curriculum or actual curriculum. ${ }^{10}$ Researchers believe that the out put who graduated from school is a reflection of how successful an educational institution implements the curriculum.

\section{B. Theoretical review}

\section{B.1. Character Education}

Character education is a system of inculcating character values to students that include components of knowledge, awareness or willingness, and actions for those values.Thus character education always directs itself to the formation of moral individuals, capable of taking decisions that appear in his behavior, as well as being able to play an active role in building a life together.11The character education in this research is the education of the values of the characters sought by the institution to the students of SDIT Ukhuwah, including knowledge, awareness, willingness and action to realize certain values that have been declared by the school as an institution.

\section{B.2. Curriculum}

Epistemologically, the definition of the curriculum is divided into two, namely the curriculum in the old view and the new (modern) view. According to the old view, the curriculum is a number of subjects that must be taken by students to obtain a diploma. The "modern" curriculum experts tend to provide a broader understanding, covering both in and out of the classroom, as well as covering everything that affects the behavior of students, including classroom cleanliness, personal teachers, attitudes of school staff, and others. ${ }^{12}$ In this study the authors more in line with the broader sense of the curriculum, the activities programmed by the school as an institution and implemented to students, either intra- curricular, co-curricular, extra- curricular and hidden curriculum.

\section{B.3. SDIT Ukhuwah}

According to KamusBesarBahasa Indonesia, the definition of primary school is an educational institution that accommodate the teaching and learning activities related to or about the basics of education. Education in elementary schools is also an activity that underlies three basic aspects, namely knowledge, attitude and skills. Elementary School National Standard (SDSN) is a school that has met the National Education Standards (SNP) which means meet the demands of the SPM so it is expected to provide standardized education services and produce graduates with competence in accordance with established national

10S. Sabda, Pengembangan Kurikulum Tinjauan Teoritis, Yogyakarta: Aswaja Pressindo, 2016, p. 32.

11S. Sabda, Pengembangan Kurikulum Tinjauan Teoritis, Yogyakarta: Aswaja Pressindo, 2016, pp. 36-38.

${ }^{12}$ Fihris, Pendidikan Karakter di Madrasah Salafiyah, Semarang: PUSLIT IAIN Walisongo, 2010, pp. 24-28. 
standards.13 The Integrated Islamic Primary School (SDIT) Ukhuwah is a primary school that blends national curriculum proclaimed by the government with an integrated Islamic school curriculum (SIT).

\section{B.4. Implementation of Curriculum as an Idea}

According to Mulyasa's view, curriculum implementation is the application of ideas, potential curriculum concepts (in the form of curriculum documents) into the actual curriculum in the form of learning process. ${ }^{14}$ In line with that understanding, the implementation of the curriculum according to Hamid Hasan is the effort to realize the ideas, concepts, and values contained in the written curriculum into reality. ${ }^{15}$ Author conclude that the real form of curriculum implementation is teaching and learning activities in the classroom, in other words teaching and learning activities in the classroom is the operationalization of the written curriculum.

\section{Findings}

C.1. The Analysis of the Idea of CharacterEducation on the Curriculum and Documents at the Integrated Islamic Primary School (SDIT) Ukhuwah in Banjarmasin

The idea of establishing SDIT Ukhuwah is the determination of its founders to create muttaqin generation and leader-character generation. SDIT Ukhuwah develops the concept of integral-holistic education based on values of tauhid, as stated in QS Al Furqan: 74 follows,

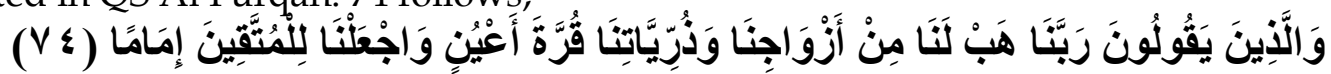

74. and those who say: "Our Lord, grant to Us Our wives and Our descendants as Our hearts, and Make Us a priest to those who are muttaqin

To achieve these goals, then SDIT Ukhuwah proclaimed the values of Islamic teachings in all educational activities. Character Values Developed at SDIT Ukhuwah are (1) SalimulAqidah (having a straight aqidah), (2)SahihulIbadah (performing worship correctly), (3)MatinulKhuluk (Having mature personality and noble character), (4)Mujahadah Li Nafsihi (independent in fulfilling the necessities of his life), (5) Mahabbah Quran (having the ability to read, memorize and understand the Qur'an well or love the Qur'an), (6) MutsaqofulFikri (having broad insight), (7) Life Skill: having a healthy body and soul (qawiyul-jismi)

\section{C.2. The Implementation of CharacterEducation on the Curriculum of Integrated Islamic Primary School (SDIT) Ukhuwah in Banjarmasin}

Through the definition that has been proposed then the implementation ofcharacter building on the 2013 curriculum in SDIT Ukhuwah can be explained as follows first, implementation as the actualization of ideas, values actualization of the plan or concept of curriculum. Second, curriculum implementation as a learning process. The third, implementation of curriculum as a process of the behavior change on students as a result of the achievment of the ideal curriculum. Starting from the four main concepts on the implementation of this

13O. Hamalik, Pengembangan Kurikulum Lembaga Pendidikan dan Pelatihan, Bandung: Trigendakarya, 1993, p. 18.

${ }^{14}$ e-journal.uajy .ac.id, accessed on April 26, 2017".

15L. J.Moleong, Metodologi Penelitian Kualitatif., Bandung: Rosdakarya, 2013. 
curriculum, it can be understood that the implementation of the curriculum will be known clearly in the learning process itself so that it can also be said that the teaching and learning process is running as the implementation of the curriculum.

\section{C.3. The Analysis of the Achievement, namely the Success of Integrated Islamic Primary School (SDIT) Ukhuwah in Realizing the Goal/Ideal CurriculumTowards the Implementation/ActualCurriculum in the Context of CharacterEducation}

In conducting assessment activities, SDIT Ukhuwah uses integrated assessment principles, which are integrated, evaluative, reliable, proportional, authentic, detail and universal.

The function of the assessment is as a consideration in determining the class increase, as a feedback in the improvement of learning process, improving student learning motivation, development of instructional system, self evaluation on teacher performance. The success of SDIT Ukhuwah in realizing the ideal curriculum is proven by the students and institution achievment both at regional and national level

D. Discussion.

\section{D.1. Character Values Developed at SDIT Ukhuwah}

The main purpose of the establishment of SDIT Ukhuwah is to realize a school that effectively develops an educational process that can foster the potential nature of the students toward the vision of the creation of a cautious and character leader generation. Based on the philosophy that refers to the messages of Islamic education as contained in the Qur'an.

SDIT Ukhuwah fostered the character of the students gradually toward the formation of a generation of intelligent and pious leaders. There are 7 main characters tought to the students, namely:

1 SalimulAqidah (having a straight aqidah); namely believing Allah SWT as Creator, Owner, Sustainer and Ruler of the universe and distanced themselves from all thoughts, attitudes and behavior of heresy, kurafat and shirk.

2 SahihulIbadah (performing worship correctly): Accustomed and fond of carrying out worship which includes: prayer, fasting, recitations of the Qur'an, dzikr and praying according to the Qur'an and Assunnah.

3 MatinulKhuluk (having Mature personality and noble character): Presents a polite, orderly, disciplined, patient, persistent and courageous attitude in the face of daily life problems.

4 Mujahadah Li Nafsihi (self-sufficient in fulfilling the necessities of his life): to be a person who seriously, discipline, and able to hold their lusts independently. Qadirun 'alalkasbi (having sufficient supply of knowledge, skill and skill in fulfilling his livelihood needs Harisun' alalwaqti (having high seriousness and motivation in pursuing school achievement, always utilizing and managing time with useful activities.

5 Mahabbah Quran (having the ability to read, memorize and understand the Qur'an well or love the Qur'an), namely the ability of students in reading the Qur'an in tartile, his habit in khatmilquran, his ability in memorizing the 
Qur'an, reading translations and Qur'anic interpretation to learn to link the values of the Qur'an in the reality of everyday life.

6 MutsaqofulFikri (having broad insight): having critical, logical, systematic and creative thinking skills that make him knowledgeable and master academic competence with the best and careful and clever in overcoming all problems encountered.

7 Life Skill: having a healthy body and soul (qawiyul-jismi), stamina and strong endurance and martial skills that are useful for himself and others, caring for others and the environment and having sensitivity to help others (nafi'un li ghairihi), orderly in arranging all tasks, duties and duties, dare to take risks but still be careful and full payback in step (munazhom fi syu'nihi).

\section{D.2. Implementation Strategies of Character Values}

Strategies implemented in the effort to carry out the mission and educational objectives are expected to support the effectiveness of the implementation of curriculum SDIT Ukhuwah are:

1 Creating a conducive school environment (bi'ahshalihah), in the dimensions of security, health, hygiene, beauty, family atmosphere (ukhuwahislamiyah), learning and worship facilities.

2 Applying the rules and norms that conform Islamic values in behaving, speaking, dressing, interacting (muamalah), tombs, drinking and other behaviors commonly practiced in the school environment.

3 Implement effective learning by enriching and expanding learning resources, enhancing stimulative interaction through integrated approaches and methods of problem-based learning and conducted in collaborative and collaborative learning approaches, as well as enhanced high-order thinking skill.

4 Development of student-centered learning, learning by doing, developing social skills, developing curiosity, imagination and fitrah god, developing problem-solving skills, developing student creativity, developing abilities, using science and technology, cultivating awareness as good citizens, life, a combination of competition, cooperation and solidarity.

5 Conducting Islamization process in learning process. The main goal of Islamization is to form an integral awareness and mindset within the Islamic perspective. Students are always invited to think and understand that all the natural phenomena that unfold and all the problems and dynamics that appear can not be separated from the role of Allah Almighty the Wise, Creator, Owner, Preserver and Regulator of the universe. With the Islamization of learning is expected to occur a strong emotional relationship between the object of discussion, students and Islamic values.

6 Strengthen student coaching program with co-curricula and extra (curriculum) curriculum, leadership coaching and effectiveness of mentoring approach (grouping students into coaching groups). SDIT Ukhuwah has a student guidance that emphasizes on the development of worship, leadership training, social awareness, such as recitations of the Qur'an, keeping wudlu, praying, fasting, praying and dhikr, alms / infak, caring to the Islamic world, caring to mustadz'afin, both parents (birrulwalidain), care about the environment and so forth. 
7 Undergo effective partnerships with various stakeholders, especially parents of students and surrounding communities. Together with parents and educators (teachers) at SDIT Ukhuwah establish cooperative communication and cooperation in an effort to improve services to students in particular and improve the quality of education in general. Equate perception and perception of school vision, mission and goals to all parents of students, resulting in alignment and continuity between school and home education through effective communication. Making effective teachers ta'lim (pengajian) teachers and parents every month.

8 Hold a full-time school (fullday school), with effective time every day for eight hours, from 7.30 to 15.30 . With a longer time, religious education and student coaching have enough discretion. A full-time school is one of the hallmarks of SDIT that appeal to parents who want their sons and daughters to stay longer in the environment and educational environment.

9 Ensuring principals and teachers have vision, mission and spirit (ghiroh and fikrah) and attitudes and behaviors become one of the characteristics of SDIT that attract parents who want their children to stay longer in the environment and education.In accordance with the philosophy, values, vision and mission of the school, SDIT Ukhuwah implements the process of selection and recruitment of principals and teachers with strict assessment criteria, including thought, attitude / morals and behavior in accordance with Islamic teachings. Each teacher recruitment process is carried out by prioritizing the dissemination of information through the network and recommendations from communities already known and trusted by school organizers.

10 Enforce the rules, norms and ethics that are made based on Islamic ethics and values (noble morals) and social decisions. Providing strict sanctions and punishments to any educator or educational staff who violate them.

\section{D.3. Principles of Character Education Implementation \\ D.3.1 Basic Philosophical Character Building}

As James A. Beane thought that the philosophical foundation is one of the three main foundations in curriculum planning.Character building on SDIT Ukhuwah students based on the following thoughts.

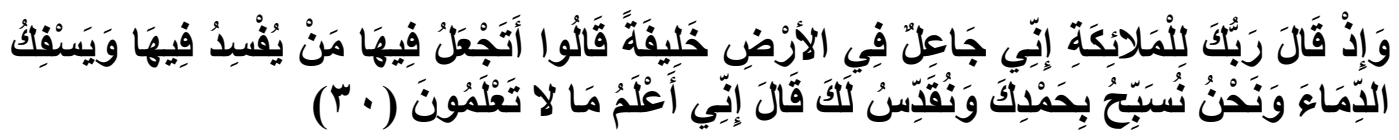

Remember when your Lord said to the Angels: "I would make a caliph in the earth." they say: "Why do You want to make the (Caliph) on earth the one who will make damage to him and shed blood, yet We always celebrate by praising You and purifying You?" The Lord said: "I know what you do not know."

Students need others to hone their social life, leadership, cooperation, communication skills, lead skills, led skills, ability to comply with rules set by the group, whether written or not. 
Character education, values and discipline within the framework of Islamic values (shahsiyyaIslamiah) become the essence of student development standards.

Organization is one means to get the opportunity to learn to lead, be led, organize, take responsibility, self-organize, put yourself, work and cooperate in spirit ukhuwahislamiyah.

\section{D.3.2. Character Building Standards}

Standard Character building guidance SDIT Ukhuwah students proclaimed to achieve the following objectives.

1. Development of Leadership and Character of the Nation

2. Social skills development

3. Entrepreneurship Development

4. Development of Islamic Healthy Living Behavior Pattern

5. Development of Lifestyle Pattern of Worship and Proud of Islamic Personality

6. Development of Interest and Talent

7. Development of reasoning and research skills

\section{D.3.3. Implementation Character Building Based on the Curriculum as an Idea}

Character building of students of SDIT Ukhuwah is implemented through extracurricular and co-curricular activities as follows.

Table 1.implementation of character building on activities at school

\begin{tabular}{|c|c|c|c|c|}
\hline No & $\begin{array}{l}\text { Character } \\
\text { Development Goals }\end{array}$ & $\begin{array}{l}\text { Character } \\
\text { Development Model }\end{array}$ & $\begin{array}{l}\text { Character Building } \\
\text { Activities }\end{array}$ & $\begin{array}{l}\text { Execution } \\
\text { Time }\end{array}$ \\
\hline 1. & $\begin{array}{l}\text { Development of } \\
\text { Leadership and } \\
\text { Character of the } \\
\text { Nation }\end{array}$ & $\begin{array}{l}\text { 1. Training } \\
\text { 2. Habituation } \\
\text { 3. Active partipation }\end{array}$ & $\begin{array}{l}\text { 1. Scouting } \\
\text { 2. Organization }\end{array}$ & $\begin{array}{l}\text { 1. Weekly } \\
\text { 2. Weekly }\end{array}$ \\
\hline 2. & $\begin{array}{l}\text { Social skills } \\
\text { development }\end{array}$ & $\begin{array}{l}\text { 1. Active } \\
\text { participation } \\
\text { 2. Direct experience }\end{array}$ & $\begin{array}{l}\text { 1. Community service } \\
\text { camp } \\
\text { 2. Social Care (visits to } \\
\text { orphanages, baksos, } \\
\text { etc.) } \\
\text { 3. Care for humanity } \\
\text { globally (concern for } \\
\text { Bosnian Muslims, } \\
\text { Palestinians, } \\
\text { Rohingyas, etc.) }\end{array}$ & $\begin{array}{l}\text { 1. } \text { Yearly } \\
\text { 2. Weekly } \\
\text { 3. Weekly }\end{array}$ \\
\hline 3. & $\begin{array}{l}\text { Entrepreneurship } \\
\text { Development }\end{array}$ & $\begin{array}{l}\text { 1. Get in the habit of } \\
\text { investing } \\
\text { 2. Simulation } \\
\text { 3. Observation } \\
\text { 4. Busines Games } \\
\text { 5. Practice of buying }\end{array}$ & $\begin{array}{l}\text { 1. Household Production } \\
\text { Skills } \\
\text { 2. Marketing skills } \\
\text { 3. Business planning } \\
\text { skills } \\
\text { 4. Training fosters an }\end{array}$ & $\begin{array}{l}\text { 1. Monthly } \\
\text { 2. Monthly } \\
\text { 3. Monthly } \\
\text { 4. Monthly }\end{array}$ \\
\hline
\end{tabular}




\begin{tabular}{|c|c|c|c|c|}
\hline & & $\begin{array}{l}\text { and selling } \\
6 . \text { Investment } \\
\text { experiments }\end{array}$ & entrepreneurial spirit & \\
\hline 4. & $\begin{array}{l}\text { Development of } \\
\text { Islamic Healthy } \\
\text { Living Behavior } \\
\text { Pattern }\end{array}$ & $\begin{array}{l}\text { 1. The practice of } \\
\text { Islamic behavior } \\
\text { 2. Mentoring }\end{array}$ & $\begin{array}{l}\text { 1. Healthy blessed food } \\
\text { program together } \\
\text { 2. Optimizing UKS, } \\
\text { Clean healthy self } \\
\text { (BSD), Clean healthy } \\
\text { environment (BSL) }\end{array}$ & $\begin{array}{ll}\text { 1. } & \text { Daily } \\
\text { 2. } & \text { Daily }\end{array}$ \\
\hline 5. & $\begin{array}{l}\text { Development of } \\
\text { Lifestyle Pattern of } \\
\text { Worship and Proud } \\
\text { of Islamic } \\
\text { Personality }\end{array}$ & $\begin{array}{l}\text { 1. Aqidah Guidance } \\
\text { 2. Guidance of Morals } \\
\text { 3. Development of } \\
\text { Worship } \\
\text { 4. Habituation }\end{array}$ & $\begin{array}{l}\text { 1. Islamic character } \\
\text { building } \\
\text { 2. The habit of worship } \\
\text { 3. Understanding and } \\
\text { implementation of the } \\
\text { Qur'an } \\
\text { 4. Community service }\end{array}$ & $\begin{array}{ll}\text { 1. } & \text { Daily } \\
\text { 2. } & \text { Daily } \\
\text { 3. } & \text { Daily } \\
\text { 4. } & \text { Monthly }\end{array}$ \\
\hline 6. & $\begin{array}{l}\text { Development of } \\
\text { Interest and Talent. }\end{array}$ & $\begin{array}{l}\text { 1. Training } \\
\text { 2. Mentoring } \\
\text { 3. Habituation }\end{array}$ & $\begin{array}{l}\text { 1. Islamic art and culture } \\
\text { 2. Martial arts } \\
\text { 3. Sports achievements } \\
\text { 4. Journalism }\end{array}$ & $\begin{array}{l}\text { 1. Weekly } \\
\text { 2. Weekly } \\
\text { 3. Weekly } \\
\text { 4. Weekly }\end{array}$ \\
\hline 7. & $\begin{array}{l}\text { Development of } \\
\text { reasoning and } \\
\text { research skills } \\
\text { Development of } \\
\text { reasoning and } \\
\text { research skills }\end{array}$ & $\begin{array}{l}\text { 1. Training } \\
\text { 2. Mentoring }\end{array}$ & $\begin{array}{l}\text { 1. Science Club } \\
\text { 2. Science Olympiad and } \\
\text { Humanities } \\
\text { 3. Technology lover } \\
\text { groups. }\end{array}$ & $\begin{array}{l}\text { 1. Weekly } \\
\text { 2. Weekly } \\
\text { 3. Weekly }\end{array}$ \\
\hline
\end{tabular}

\section{E. Conclusion}

SDIT Ukhuwah is a primary educational institution that integrates national curriculum system (Kemendikbud) with an integrated system of Islamic education curriculum (JSIT) which is influenced by Hassan Al-Bana's idea on Tarbiyah. Implementation of character education is integrated into all subjects, taught as an integrated curriculum model. Character education is developed with the model of habituation, coaching, training, mentoring, observation, simulation and experiment. This research indicates that SDIT Ukhuwah targets its graduates to have good character, that is having leadership and character of the nation, possessing social skill, life skill and entrepreneur spirit, having healthy Islamic lifestyle pattern, having lifestyle of worship and proud of islamic personality (owning aqidah the righteous, perform the worship according to the Qur'an and sunnah, strong personality and noble character), able to develop themselves according to interests and talents, have reasoning and research skills. This study found that SDIT Ukhuwah developed the concept of integral holistic education based on tauhidvalue. Students not only teach the content of basic education and Islamic science written in the curriculum, but also taught to be a complete Muslim personality, equipped with the skills, characters and knowledge needed. The teachings are conducted in the religious routine activities that are vertical (element of ritual worship) and horizontal (element of worship associated with 
others). Activities are conducted in four stages, namely daily, weekly, monthly and yearly.

\section{Bibliography}

e-journal.uajy .ac.id, accessed on April 26, 2017".

http://liputan6.com/tag/kenakalan-remaja," [Online]. Available: http://liputan6.com/tag/kenakalan-remaja. [Accessed 27 September 2017].

D. K. A, Pendidikan Karakter Utuh menyeluruh, Yogyakarta: Kanisius, 2016,

D. Koesoema, Pendidikan Karakter Utuh dan Menyeluruh, Yogyakarta: Kanisius, 2016,

d. Muchlas Samani, Konsep dan Model Pendidikan Karakter, Bandung: Rosdakarya, 2013,

Fihris, Pendidikan Karakter di Madrasah Salafiyah, Semarang: PUSLIT IAIN Walisongo, 2010,

L. Hasibuan, Kurikulum dan Pemikiran Pendidikan, Jakarta: GP Press, 2010,

L. J.Moleong, Metodologi Penelitian Kualitatif., Bandung: Rosdakarya, 2013.

M. Wahid, "Pengembangan Model Pendidikan Afeksi beroriantasi Konsiderasi Untuk Membangun Karakter Siswa ang Humanis di Sekolah Menengah Kejuruan," in The 4th International Conference on Teacher Education; Join Conference UPI \& UPSI, Bandung, 2010.

O. Hamalik, Pengembangan Kurikulum Lembaga Pendidikan dan Pelatihan, Bandung: Trigendakarya, 1993

S. Sabda, Pengembangan Kurikulum Tinjauan Teoritis, Yogyakarta: Aswaja Pressindo, 2016,

T. Lickona, Educating for Character: How Our Schools can Teach Respect and Responsibility, New York: Bantam Book, 1992 